\title{
아크라 행동계획(AAA) 채택의 의의와 정책적 시사점
}

초| 성 호 / 한국국제헙력단 정책연구실장

2008년 9월 2일부터 3일간 130 여 개국 1,500여명이 참석한 가운데 개최된 '제3차 원즈효과 제고를 위한 고위급회의' (The 3rd High Level Forum on Aid Effectiveness)에서 채택된 아크라 행동계 획(Accra Agenda for Action, AAA)의 의의와 정책적 시사점에 대해 알아본다.

\section{I. 개괄}

서부 아프리카 대서양 연안에 위치한 인구 2,260 만 명의 가나의 수도 아크라에서는 지난 9 윌 2 일부터 4 일까지 가나, 라이베러아, 온두라스 등 수원구 3 개국 정상을 비롯하여 공여구, , 신흥공여구 및 수원국의 각료급 인사, 국 제기구 대표, 시민사회 등 130 여 개국(기관) 1,500 여명이 참석한 가운데 '제 3 차 원조효과 제고를 위한 고위급회 의 (The Brd High Tevel Forum on Aid Fffectiveness)가 기최되었다.

금번 회의는 2005년 제2차 고위급회의에서 채택된 원조효과 제고에 관한 파리선언(Paris Declaration on Aid Effectiveness)의 이행과 관련하여 중간 점검하는 각료급 회의로서 본회의 및 9 개 원탁회의에서 실질적인 원조효 과 개선 및 원조의 진적 제고 방안을 폭넓 게 논의하고, 회의 최종일에는 파리선언의 2010 년 목표달성을 촉구하 기 위한 아크라 행동계획(Accra Agenda for Action, AAA)을 채택하였다.

우리 정부는 오준 외교부 다자외교조약실장을 수석대표로 외교부, 기재부, $\mathrm{KOICA}$ 수출입은행 등으로 구성된 대표단이 참석하였으며, 특히 본회의 기즈연선을 통해 non-DAC 공여국 대표로서 원조효과 제고 방인 관련 우 리의 입장을 피력하였다. 우리측 수석대표는 기조연설을 통해 우리의 과기 기발겅험에 비추어 원조의 질적 제고 
와 효과성을 위한 가이드라인인 파리선언과 원칙을 전적으로 지지하며, 전통공여국, 신흥공여국, 수원국을 포함한 모든 개발협력 주체들의 오너쉽 강화와 상호보완적 역할의 필요성, 포괄적 파트너십 구축 (comprehensiveness) 및 각 개별주체별 역량과 상황을 고러한 신축적 접근(flexibility)의 중요성을 강조하였다. 또한 2010 년 $\mathrm{OECD} / \mathrm{DAC}$ 가입을 앞두고 수원국과 공여국의 경험을 모두 갖춘 우리나라가 원조의 양적, 질적 측 면에서 개반협력 노력을 강화할 의지가 있음을 밝혔다.

\section{II. 원조효과성 제고 논의배경- 왜 원조효과성인가?}

1990년대 후반기 이후 게발원조 규모는 지속적으로 증가하였으나, 최근 국제사회에서는 게발협력의 목표설정이 개발재원 확대에 느치시 않고, 실질적인 성과를 중시하는 원조의 질적 수준 제고로 이어셔야 한다는 인식이 확대 되었다. 지난 반세기 동안의 기존의 원조관행에 내한 자성과 함께 득히 2015 년 천년 개발목표(MDGs)의 세부지표 를 목표 시한 내 딜성하기 위해서는 실질적인 원조성과를 제고하는 방향으로 원조시스템이 바뀌어야 한다는 공 감대가 형성되고 있다.

또한, 개발원조가 기존의 원조공여구 개발체계에서 수원국의 오너쉽 확립과 공여구과 수원국간 파트너십을 강조 하고, 사입단위 원조방식(Project Approach)에서 중기프로그램(Modium-term Program)으로 원조니용이 변화 하며, 최근 들어 급속히 성장하는 신흥공여국, 글로 벌 펀드, 시민사회와 같은 새루운 원조주체들과의 협력적 파 트너십의 강화 필요성이 더욱 제기 되는 등 21세기 원조체계(Aid Architecture)의 변화를 반영한다고 할 수 있다. 결과적으로 개발원조사업의 이행(Output) 자체보다는 사업을 통한 해당 번야의 결과 및 개선사항(Outcome), 파 급효과(Impact)에 보다 중점을 두고 있는 것이다.

\section{III. 파리선언의 이행 상황}

국제사회는 원조효과성 제고를 위한 노력의 견신로 '몬테레이 킨센서스' (2002년), '원좆ㅈ화를 위한 루마선언' (2003년), '기발성과 관리를 위한 마라케시 공동메로랜덤’ (2004년)을 도출하였으며, 이의 종합판인 ‘원조효과 제고에 관한 퐈리선언' (2005년)을 발표하고 2010년까지 이행키로 합의하였다.

파리신언은 크게 5 대 원칙 및 5 대 원칙의 성과지표로서 2010 년까지 달성목표를 설징한 12 개의 측정지표로 구분 
된다. 첫째, 공여국은 수원국 리더십을 존중하고 수원국은 기발전락의 입안 및 이행에 주도적 역할을 수행한다는 수원국의 오너쉽(Ownership), 둘째, 공여국은 수원국의 개발전략에 원조를 일치 시키고 강화된 수원국의 시스템 의 할용, 수원국의 정부조달 시스템의 강화, 원조의 언타이드화 등을 규정한 원조의 일치(Alignment), 셋째, 공 여국은 원조활동에 대한 공동의 합의사항을 이행하고 원조절차를 간소화하녀, 보다 효과적인 원조의 분업 (division of labor) 등을 제시한 공여국간 원좆ㅈ확(Harmonization), 넷째, 공여국은 수원국의 개반전략 수립과 자원을 성과에 연계시키고, 수원국은 성과 중심적 보고 · 평가체제를 구축하는 것을 골자로 한 성과중심의 관리 (Managing for results), 다섯째, 공여국은 수원국 정부가 의회 및 국민에게 예산보고를 할 수 있도록 원조제공 에 대해 투명하고 포괄적인 정보를 제공하고, 수원국은 국가개발전략 이행 및 평가에 다양한 개발주체들을 찬여 시키는 것을 나용으로 하는 공여국과 수원국간 상호책임성(Mutual Accountability) 등이다.

\section{1. 수원국의 오너십}

수원국이 개빌징책, 전략 및 원조활동을 직극직으로 조징하고 주도하는 것을 의미하는 오너 쉽과 관련, 대부분의 수원국에서 국가기발정책 및 전략이 강화되고 있으나, 이를 부문별 전략과 성과중심의 분권화된 운영 프로그램 에 반영하는 데는 아직 어려움을 겪고 있으며, 오너쉽에 대한 지지를 구체화하기 위한 내부 정치, 행정시스템의 제야도큰 편이다.

\section{2. 원조의 일치}

공여국 위주의 일방적인 원조가 아닌, 수원국의 개발전략, 제도 및 절차에 맞게 원조를 일치시키는 것을 의미하 는 원조의 일치와 관련, 수원국 우신순위에 따른 원조에는 많은 개선이 있있으나, 사업 수행기관의 중복을 줄이 고 역량강화를 위한 지원을 강화하는 데는 미미한 신정이다. 정책 및 전략단계에서의 일치는 큰 어려움이 없으 나, 실제 운영 · 시행단 계에서 많은 장애물이 있는 것으로 니타난다.

\section{3. 공여국간 원조조화}

공여국간 원조활동이 서로 상충되지 않고 투명하며 호율적으로 협력하기 위한 원조조화의 문제는 원조의 분업을 퉁한 회원국 간 조화를 강조한 EU의 해동강령 (code of conduct)을 제외하고는 전반적으로 가시적인 진전도 퇴보 도 없는 상황이다. 원조조화의 목표달성을 위해서는 수원국 시스텐에 내한 신뢰가 가장 중요하녀, 다른 원칙과 마찬가지로 수원국 리더십, 이니셔티브 및 지원이 필수적이다. 


\section{4. 성과중심의 관리}

성과중십의 관리와 관련, 수원국 동계여량을 강화하고 의사결정을 위해 이를 보다 효율적으로 활용해야 할 필요 성이 제기되고 있다. 공여국 역시 수원국 시스템 효율성 제고를 지원함과 동시에 자국 시스템을 정비할 필요가 있다.

\section{5. 공여국 · 수원국간 상호책임성}

상호책임성과 관련, 원조효과 제고 성과를 측정하고 문제를 해걸하기 위한 협력이 제대로 이루어지지 않고 있다. 공여국은 원조예측성 강화를 위해 원조제공 관련 투명하고 포괄적인 정보를 제공해야 하며, 수원국과 공여국은 원조효과성 관련 합의된 상호 이행성과를 공동 평가해야 한다.

\section{$\mathbb{N}$. 아크라 행동계획 $(\mathrm{AAA})$ - 파리선언의 보완}

금빈 아크라 고위급회의에서는 전반적으로 변화하는 국제원조체제에서 원조효과성 제고를 위한 파리신언의 제 반 원칙들의 논의 확대와 현신적 이행 필오성이 제기되었다. 우리측은 변화하는 국제원조체제 정립을 위해시는 각 기발주체간 정보공게 등을 강화하여 이해와 신뢰를 제고하고 포괄적 파트너십을 강화하는 한편, 현실적이고 신축적인 접근이 중요함을 강조하었다. 즉, 전통공여국이 non-DAC 공여국의 개발역량을 시원하고, 신흥공여국 을 국제원조체제에 편입시키녀, 남남협려, 산각협력의 활성화를 위해 전통공여국과의 연계를 강화하여야 함을 강조하였다.

$\mathrm{AAA}$ 는 첫째, 개발에 대한 수원국의 오너쉽 강화, 둘째, 호과적, 포괄적 개발 파트너십 구축, 셋째, 개발성과 도출 및 책임강화 등을 핵십사안으로 수원국 주도의 원조효과 제고 방안을 모색하였다. AAA는 130 여 개국(기관) 각료 급 인사들의 참여하에 다양한 개발 파트너와의 포괄적 협의과징을 거쳐 채택함으로써 원조효과 제고를 위한 정 치적 의지 강화의 계기가 되었으며, 2005년 파리선언에 비해 수원국 시스템의 활용, 원조 예측가능성 게선 등 수 원국 입장이 상당부분 반영 된 진일보된 것으로 평가된다.

금빈 $\mathrm{AAA}$ 채택 으로 그동안 이행성과가 미진한 파리신언을 보완하여 2010 년 목표년도까지 원조효과 제고를 위 한 이행점검이 진행될 예정이며, 현행 국제원즈체제에서 각 개반협력 주체는 수원국의 오너쉽 제고 및 역량강화, 
공여국과 수원국간 상호책임성 강화 등을 통한 구체적인 이행방안을 마련함으로써 원조효과성 제고에 실질적으 로 기여할수 있을 것으로 기대된다.

\section{1. $\mathrm{AAA}$ 의 주요내용 및 우리의 이행계획 방안}

금번 $\mathrm{AAA}$ 에서 강조하고 있는 주요 내용을 확인하고, 이에 대한 우리의 향후 이행계획 추진방안을 아래와 같이 정리해 보았다. 동 추진방안은 아직 은 정부차원에서 확정된 사항이 아닌 검토단계이며, AAA도 파리 선언과 함께 $\mathrm{OECD/DAC}$ 의 원조 작업반 주도로 중간평가 등 이행과정을 전검할 예정이다.

\section{가. 수원국 오너십 제고 및 수원국내 개발정책대화 활성화}

(제13항 Ownership, Country-level policy dialogue on development)

\begin{tabular}{|c|c|}
\hline 수원국 & 공여국 \\
\hline $\begin{array}{l}\text { - 수원국 정부는 의회, 지방정부, 시민단체등과 공동으로 국 } \\
\text { 가개발점 책 및 계획수립 · 이햄 }\end{array}$ & - 공여 국은 수원국나 개발정책대화 존중 및 촉진 \\
\hline $\begin{array}{l}\text { - 개발정책 및 프로그램을 인류공동문제(cross-cutting 이슈) } \\
\text { 괸해 합의된 국제 공약에 일치 }\end{array}$ & $\begin{array}{l}\text { - 원조 프로그램과 개발정책을 성폄 듬 인권, 장애, 환경 적 지 } \\
\text { 속가능성 등 인류 공동문제에 관해 합의된 국제 공약에 일치 }\end{array}$ \\
\hline $\begin{array}{l}\text { (공통사항) } \\
\text { - 정책대화 존중 및 촉진 } \\
\text { • 인류전체의 공동문제별 우리 기본정책 수립 및 개발정책에 }\end{array}$ & 영 모색 \\
\hline
\end{tabular}

- 원조 프로그램과 게발정책을 인권, 환경, 성펑등 등 인류 공동문제(cross-cutting issues) 관련 합의된 국제 공약에 합치 되도록 이행

어엉평 등, 인권, 환경적 지속가능성 제고에 효과적인 사업 발굴 및 원조시행기관 practices 개선, 역랑강화

\section{나. 역량강화 및기술협력 제고}

(제 $13 b$ 항 \& 제14항 Capacity development and Technical cooperation)

\begin{tabular}{|c|c|}
\hline 수웍극 & 긍여극 \\
\hline $\begin{array}{l}\text { - 수원국은 역량강화가 필요한 분이를 신별하고 역량개발 전 } \\
\text { 략 수립 } \\
\text { - 수원국과 공여국은 공동으로 기술협력 사업을 선별, 괸리 } \\
\text { 하며, 지역지원 활용을 촉진하고, 보다 효과적인 역량강화 } \\
\text { 위해 사업운영 개선 }\end{array}$ & $\begin{array}{l}\text { - 공여 국 자신의 역량강화 } \\
\text { - 의회, 중앙 - 지방정부, 시민단체, 연구기관, 언론 등 수원국 } \\
\text { 역량깅화 지원 대상 다변화 } \\
\text { - 수요줌심의 기술협력, 역량강화 사업 운영을 위해 수원국 } \\
\text { 과 공동으로 기술협력사업 선별, 관리 및 남남협력 등을 통 } \\
\text { 한 수원국나, 역내 전문성 촉진 }\end{array}$ \\
\hline
\end{tabular}




\section{(공통사항)}

- 우리의 개발역량 강화

- 기술협력 사업 공동 결정 및 남남협력 활성화 지원

- 어리의 포괄적 개발협력 능력 배양 강화 계획 수립

이역별, 분야별 전문성 강화 등 원조집행기관 역량 강화 추진

- 수원국 역량강화 지원대상 다변화

으주요 수원국에서 의회, 시방정부, 시민난체와의 파트너십 강화 추진

- 수원국 수오에 기반한 기술협력(TC), 능력배양(CD) 사업 효율화 추진

암남협력 통한 역내 기술협력 촉진 지원 방안 수립

\section{다. 수원국 시스템 사용 강화 (제 15 항 Country systems)}

\begin{tabular}{|c|c|}
\hline 수원국 & 공여국 \\
\hline $\begin{array}{l}\text { - 수원국은 공여국과 함께 자국 시스템의 질을 평가하고 개 } \\
\text { 혁 프로그람 선정과 우선순위 결정을 주도 }\end{array}$ & $\begin{array}{l}\text { - 공공분야 지원사업시 수원국 시스템 시용을 우선적으로 고 } \\
\text { 려. 수원국 시스템 미사용시 그 사유 공개 및 정기적으로 } \\
\text { 재검토 } \\
\text { - 공여 국은 수원국과 수워국 시스템의 질을 공동 평가 } \\
\text { - 수원국 시스템 사용 계획 즉시 수립 } \\
\text { - 정부간 지원시 } 2010 \text { 까지 수원국 재정 시스템 } 50 \% \text { 이상 사 } \\
\text { 용 } \\
\text { - 원조의 } 66 \% \text { 를 프로그램 원조로 지원한다는 파리선언 공 }\end{array}$ \\
\hline \multicolumn{2}{|c|}{$\begin{array}{l}\text { (공통사항) } \\
\text { - 수원국 시스템 사용 확대 계획 수립 - 예산지원(budget support) 검토 \& 수원국 재정 시스템 확대 사용 계획 } \\
\text { •프로그램 접근 원조 강화 }\end{array}$} \\
\hline
\end{tabular}

- 수원국 시스텐 사용 제고 Roadmap 수립

이 사용 검토 대상 수원국 시스템의 구체적 범위 견정 및 인본 등 주오국 시례 검토

○ Roadmap 수립

- 수원국 시스템 공동평가 실시 $\rightarrow$ 수원국의 시스템 개선을 위한 체계적 기술협력 실시 $\rightarrow$ 중전 수원국별 시스텐 사용 확내 중장기 맛춤형 계획 수립 $\rightarrow$ 수원국 시스텝 비사용시 사유 공개 및 정기적으로 재검토 $\rightarrow$ 현지 직원 가이드라인 마련 및 교육·훈련 제공 


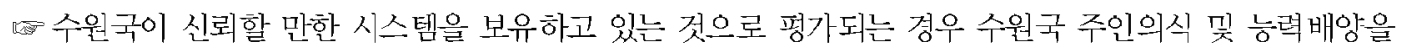
위해 수원국 시스템 활용-강화

※ 시스템 미사용시 이유 공개 및 정기적으로 재검토하도록 내부 시침 수립

0 수원국 시스템 공동평가 실시

- 인본 또는 호주, 아시아 수원국과 공동평가 우선 추진 검토(삼각협력방식의 수원국 공동평가)

- 수원국 시스템 사용- 시범(pilot) 국가 선정

으수원국 시스템 질 개선위한 체계적 역량강화 시원 및 시속적인 모니터링 수행 조진

- 일회적 기술원조를 지양하고 기술원조 사업을 체계적으로 관라하여 수원국 시스텐 질 개선에 실질적 도 움이 되도록 모색

- 프로-리램 접근 강화(program-based assistance: PBA)

언ㄹㄴㄱ략적 이해관계 분야가 같은 공여국(중간소득구가 포함)과 pilot 국가를 대상으로 공동기금 조성 등을 동

한 $\mathrm{PBA}$ 공동사입 추진 검토

- 중장기적으로 '선택과 집중' 원칙에 기반, PBA 사업, 예산지원 추진

으에산지원(b udget support) 활용- 검토

라. 원조 분산화 감소 (제17항 Reducing aid Fragmentation)

\begin{tabular}{|l|l|}
\hline \multicolumn{1}{|c|}{ 수원극 } & \multicolumn{1}{c|}{ 공여국 } \\
\hline • 수원국 주도 원조조화 & $\begin{array}{l}\text { - 원조효과작업반 주도로 원조분업 원칙 모범사례 수립 } \\
\text {-2009.6월까지 국제 원조분업 및 원조 소외국 문제 논의 시작 }\end{array}$ \\
\hline $\begin{array}{l}\text { (공통사항) } \\
\text { - 원조분업 } \\
\text { - 개발협력 조화(coordination of develop ment co-operation) 계획 수립 } \\
\text { - 원조효과작업반 참여 }\end{array}$ \\
\hline
\end{tabular}

- 원조분업 관련 향후 논의 내비 우러 입장 및 중장기 계획 수립 추진

우우리의 중점지원 지역, 국가, 분야 재검토 중점지원국 축소방향 수립

- 국제 원조분업 논의가 우리 ODA 정책과사업에 미칠 영향에 포괄적 분석

이리본, 호주 등과 아시아지역내 원조조화(harmonisation) 논의 참어 검토

$-\mathrm{EU}$, 유럽 국가 등이 주도하는 논의에 내한 적극적 나응 방안 바련

0 수원국내 공여국회의 참여 강화와 공동협력 사업 확대 
- 원조효과작업반 참여 추진!

0 2009.6월까지 시작할 원조효과작업반 주도 논의에 적극 참여

○ 원조효과작업반 회원자겨 변경, mandate 개혁작업 에의주시, 찬여 추진

마. 원조의 가치제고 (제 18 항 Increasing aid s value for money)

\begin{tabular}{|l|l|}
\hline \multicolumn{1}{|c|}{ 수원국 } & \multicolumn{1}{c|}{ 공여국 } \\
\hline • 기업의 사회적 책임(CSR)에 관한 국제적 합의 준수 & $\begin{array}{l}\text { ・원조 언타이드 구체 계획 수립, 조달절차 투명성 강화 및 } \\
\text { 현지 기업의 조달시잠 참여 지원 } \\
\text { •기업의 사회적 책임(CSR)에 괸한 국제적 합의 준수 }\end{array}$ \\
\hline $\begin{array}{l}\text { (공통사함) } \\
\text { - 유· 무상 원조의 언타이드 구체 계획 수립 및 이햄 } \\
\text { • 조달체제 선진화 } \\
\text { - CSR 홍보 강화 }\end{array}$ \\
\hline
\end{tabular}

- 관계부처 협의에 따라 유 - 무상 원조 언타이드화 구체적 계획 수립 및 이행

$\circ \mathrm{DAC}$ 가이드라인에 부합하는 비구속성 원조 확대계획 수립, 추진

- 최빈구 및 HIPCs 국가를 우선적으로 고려

- 조달시장 선진화, 투명화 계획 수립 및 이행

- CSR 관련 관련기관, 기업, 시민단체 등 인식제고 위한 홍보계획 수립

바. 개발 파트너 확대 - 포용 (제19항 Enlarging the tent - welcoming all development partners)

\begin{tabular}{|c|}
\hline $\begin{array}{l}\text { •남남협력 포함한 모든 개발 행위자들이 파리선언 원칙 준수 } \\
\text { · 중간소득 국가들의 경험을 공유하고 삼각협력 촉진 } \\
\text { • 글로벌 펀드는 분이별 정책과 제도 개선을 원조 일치, 조화 참여 및 기존 윈조채널 활용 }\end{array}$ \\
\hline $\begin{array}{l}\text { •남남협력 지원 } \\
\text { •삼각헙력 활성화 } \\
\text { •글로벌 펀드 정책 다련 }\end{array}$ \\
\hline
\end{tabular}

- 남남협력 지원 계획 수립

O ODA사업에 남남협력 활용- 제고 방안 모색 
- 삼각협력 활성화 계획

으르로 그램 접는 획대, 원조분업 논의 등에 능동적침여 위한 삼각협려 활성화 추진

- Global funds, programme 지원관련 원조효과 제고위한 종합정책 수립

으 중점 지원분야 글루 벌 펀드 선별, 중점 지원

사. 시민사회 참여 제고 (제20항 Civil society)

- 시민단체의 활동에 우호적인 환경 제공

- 정부 프로그램 과의 조율: 시민단체의 결과에 대한 책임성 및 시민단체 활동 정보공개 강화 등을 위해 공동 노력

- 시민단체의 관점에서 파리선언 원칙 준수 검토

- 시민단체의 표리선언 원칙 준수 촉구

- 시민단체기여 강화 환경 조성

- 시민딘체 역량강화 지원 전략수립

0 시민사회와 원조정책에 대한 대화 확대

$0 \mathrm{NGO}$ 통한 ODA 사업 모니터링 및 평가 강화 방안 수립

- 수원국 시민단체 지원 및 활용 제고 방안 수립

아. 취약국가 개발원조정책 개선 (제21항 Fragile situations)

- 국가수준에서 공여국과 수원국은 자발적으로 취약 국가와 상홤에서 모범 국제개입 원칙(Frinciples for Good Intemational Engagement in Fragile States and Situations) 이행을 모니터

a) 공여 국은 수원국 당국 등과 가버넌스 및 능력 공동 평가, 분쟁 · 취약 · 불안의 원인 조사 실시

b) 현실적인 평화 및 국가건설 목표 수립, 분쟁 - 취 약상태의 근본 원인 해결, 여성 보호 및 참여 보장

c) 핵심 국가기능 및 조기 복구를 위한 수요 중심의 맞춤형, 조율된 능력 배양 지원 제공

d) 유연하고 신속한 장기적인 공동의 재원조달 방식 수립, 적절한 경우 인도적 지원, 복구지원을 장기 개발지원 과 연계 및 안 정화, 포괄적 평화구축 및 국가건설과 연계, UN 시스템, 국제금융기구 등과의 파트너쉽 촉진

- 취약 · 분쟁국가 원조정책

- 인도적 지원과 ODA 연계 강화

- 분쟁 및 췩약국가 원조시 'Principles for Good International Engagement in Fragile States and Situations' 적용 현황 파악

운쟁 및 취약국가 ODA 지원시 동 원칙 반형 강화 
- 분쟁 및 취약국가관련 $\mathrm{ODA}$ 전문성 제고

자. 성과 관리 (제23항 Managing for results)

\begin{tabular}{|c|c|}
\hline 수원국 & 공여국 \\
\hline $\begin{array}{l}\text { - 정보 시스템 개선 - 비용효과적인 성과관리 수단 개발 } \\
\text { - 공여국과 공동으로 성과관리 수단 가발 및 다른 정보원과 } \\
\text { 조율, 연계 }\end{array}$ & $\begin{array}{l}\text { - 수원국 정보시스템과 공여국 모니터림 연계 및 수원국 통 } \\
\text { 계능력, 정보 시스템 강화 지원 } \\
\text { - 체계 적으로 제도적, 행정적 장애 요소를 검토하여 원조효과 } \\
\text { 를 위한 인센티브 강화 } \\
\text { - 현지 시무소에 춤분한 권한 이양 }\end{array}$ \\
\hline
\end{tabular}

- 사업 모니터링을 위한 수원국 정보시스템활영 증대

으수원국 통계, 정보시스템 강화 시원 - 수원국 능력배양을 위한 기술협력(TC)과 연계

- 원즈효과 제고

으제도적, 행정적 장애.요소 포괄적 검토 및 체계적 개선 추진

ㅇ원조효과 제고를 위한 인센티브 마련

- 원즈기관 현지 사무소(oountry office) 권한 강화

차. 결과에 대한 책임 (제24항 \& 제26b항 Accountability for results)

- 공여국은 원조 규모 · 분배 · 지출결과에 대한 정기적이고 상세한, 시의적절한 정보 제공

- 수원국은 공공재정관리에 대한 의회 감독 촉진

- 2010년까지 모든 국가에서 상호평가검토 추진

- 2009년 말까지 국제 상호책임 검토 추진

- 불법취득 자산 추적, 동결, 원상회복

- 투명성(tran sparency) \& 책임(accountability) 강화

- 상호폄가검토(mutual assessment review) 시햄

- 매년 ODA 공약 및 실질 집햄액에 대한 완전하고 시의적절한 정보 제공

- 상호펑가(mutual assessment) 검토 시행계획 수립 0 중점 지원국 중심으로 상호평가 단계적으로 확대 실시 
- 원조 투명 성 강화

으수원국별 원조 규모 · 분배· 지출 결과 정기적으로 공개

카. 원조조건 (제25항 Conditionality)

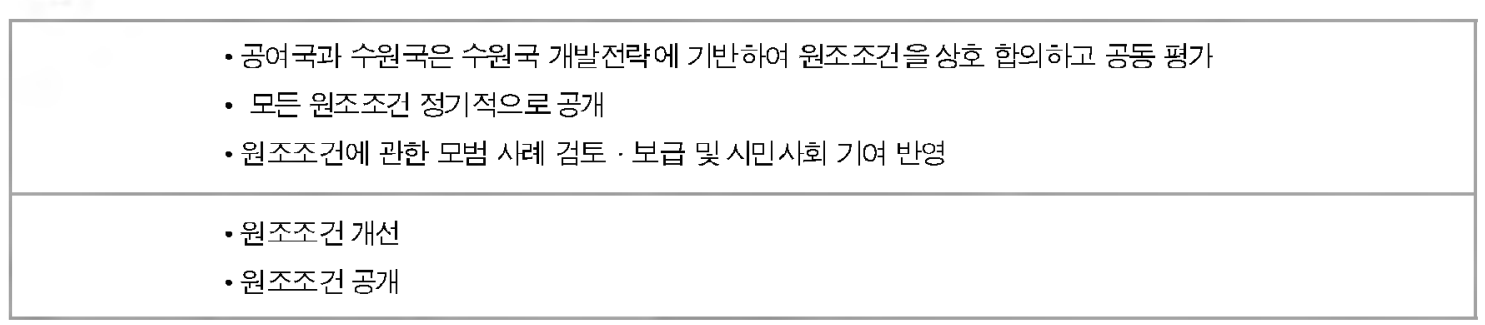

- 우리 원조사업의 원조조건 부과 현황 검토 낓 개선 추진

O ODA 정책의 기본목표 수립시 인류공동문제(cross-cutting issu e) 등 원조효과 제고위한 원조조건 비과 검토

- 즈긴(conditionality) 공개 강화

0 시민단체와의 협의 강화

타. 중기 예측가능성 (제26항 Medium-term predictability)

\begin{tabular}{|c|c|}
\hline 수원극 & 공여국 \\
\hline - 예산 기획 과정을 강화하고 성과에 기반한 지출 & $\begin{array}{l}\text { - 매년 원조공약 및 실질 집햄액 정보 공개 } \\
\text { - 중기(3-5년) 원조계획 체계적으로 제공 } \\
\text { - 중기예측가능성 제고를 위한 국제대화 촉진 및 이행평가 } \\
\text { 수단 개발 }\end{array}$ \\
\hline
\end{tabular}

- 매년 원조공약 규모 및 실질 집행액 공기

어ㅁㅓㅓㅇ부적 $\mathrm{ODA}$ 통계 시스템 강화

애내년 초 원조공약 규모 및 전년도 실질 집행액 공개

- 중기 예측가능성 제고방안 수립

우우리 정부의 중기 ODA 목표수립 및 이행점검

ㅇ 이선 중점헙력 대상국의 국별시원전략(CAS) 수립시, 최소 제공 범위의 중장기 원조제공 공약을 포함하고, 원조호과에 대한 공동평가를 기초로 원조액 증감하는 방안 김토 
O ODA 시업을 중기단위 산업 중심으로 기획 · 집행 추진

- 수원국 수요에 부합하는 중장기 원조계획 수립 위해 수원국의 중장기적 원조수요 에측 능려제고

파. 아크라행동계획 이행 (제28항, 제30항 \& 제31항 Implementation of the AAA)

· 공여국은 수원국의 국별 행동계획 수립 지원 (구체적인 시한설정 및 모니터링 가능한)

- 원조효과작업반이 2010년 파리선언 및 AAA 모든 공약 모니터링 및 평가 실시

- 다양한 개발주체가 참여하는 수원국과의 공동 파트너쉽을 위한 제도적 프로세스 개발

- UN 시스템과 연계

- 2010년 파리선언, AAA 이행 모니터링 실시

- $\mathrm{AAA}$ 구체적인 이행 계획 수립 및 단계적 이행 추진

윽관계기관(재정부, $\mathrm{KOICA}$, 수은 등) 협의하여 각 공약사항별 입장 정립 밎 구체적 이행 계획 수립

- 향후 $\mathrm{AAA}$ 해석과 이행에 관한 원조효과작업반 회의에 적극 찬여

- 원조분입, 수원국 시스템 사용 등 쟁짐 분야관련 전략직 이해관계 고려 여타 공여국과 공조체제 모색

$0 \mathrm{AAA}$ 및 $\mathrm{AAA}$ 이행계획을 적극 홍보하고 실질적 원조효과 제고 추진

- 관계기관, 공관, 시민단체, 기업 등 포괄적 접는

\section{V. 정책적 시사점}

\section{1. 원조추진체제와 운용의 선진화}

오는 2010년 DAC 가입과 2015 년 ODA 규모를 GNI 대비 0.25\%가지 끌어올려(제4차 국제개발협력위원회) 명신 상부한 선진공여국으로 발돋움하려는 우리 정부로서는 수원국 주도의 기발 지원, 파트너십 강화를 통한 원조조 화 증진, 수원국 역량강화 시원 등 원조효과성 제고를 위해 국제원조규범을 준수하고 이를 모니터링, 평가할 수 있는 원조추진체제와 수행방식의 개선이 필요하다. 즉, 원조사업의 발굴, 십사단계에서부터 원조효과를 예측하 고, 사업의 진행 모니터링 및 평가까지 성과관리 중심의 원조사업 추진과 평가체제 구축이 필요하다. 이를 위해 관계부처와 유관기관, 시민사회 등 게발협력 주체들간 우리 기발원조의 선진화 노려을 위한 단계적인 실천방안 을 강구해야 할 것이다.

\section{2. 포괄적 파트너십을 통한 원조조화}


금번 회의는 $\mathrm{AAA}$ 도출과정에서도 관찰되었듯이 유럽, $\mathrm{FU}$ 등을 중심으로 한 전통적인 공여국 외에 신흥공여국 의 부상, 글로벌펀드, 시민사회 등의 역할증대 등 국제원조체제의 다양화와 변화추세가반영되었다. 향후 다양한 개발협력 주체간 상호책임성, 정보공유 강화 등을 위해 포괄적 파트너십 활성화가 예상되므로 새로운 개발협력 모델 및 우수사레(best practices)를 적극 발전시켜 국제 개발원조 논의에 기여할 필요가 있다. 뜨한, 수원국내 원 조공여국 회의에 적극 침여하여 타 공여국과 상호. 보완적인 원조를 시행하기 위한 ODA 정책 대화를 횔성화하여 우리의 개발역량을 증진시키는 계기로 활용-하여야한다.

\section{3. 시민사회의 개발역량 확충}

한편 최빈국에서 공여국으로 탈바꿈한 우리의 독특한 위치를 최대한 활용하여 우리의 성공사례 및 노하우를 발 전시켜 수원국의 국가개발전략, 사업 정책 분야의 개발컨설팅 확대 등 개발경험의 공유를 할성화하고, 수원국과 공여구간, 전동공여구과 신흥공여구간 촉내제 여할을 수행할 필요가 있다. 득히, 금번 회의에서 시민사회, 언론, 국제기구 등 비국가 주체의 참여가 두드러졌음이 확인되있는 바, 우리의 개발 경험 공유 및 원조호과성제고를 위 해서도 국내의 기발 NGO를 비룻한 시민사회의 기발원조 역랑을 확충하는데 전략적 지원이 필요할 것으로 본다. 이러한 맥락에서 KOICA는 무상원조사업의 효과제고를 위한 민간부문의 참여확대를 위해 2008년도 민간단체지 원 사업비(100어원)를 전년 대비 $109 \%$ 증액하였으녀, 신규 협럭사업으로 원조사업에 민간부문 찬여를 확대하고 개빌원조에 대한 이해증진과 지지기반 확대를 위해 $\mathrm{NGO}$ 의 개빌인지 교육지원 등 민간단체를 통한 '개빌협력 인지강화 프르 그램'을 추진할 계획이다. 